\title{
P05.26. Systematic review of breastfeeding and herbs
}

\author{
K Budzynska ${ }^{*}$, Z Gardner ${ }^{2}$, J Duguoa ${ }^{3}$, T Low Dog ${ }^{4}$, P Gardiner $^{1}$ \\ From International Research Congress on Integrative Medicine and Health 2012 \\ Portland, Oregon, USA. 15-18 May 2012
}

\section{Purpose}

Despite popular and historical use, there has been little modern research conducted to determine the safety and efficacy of herb use during breastfeeding. The purpose of this study was to systematically review the clinical literature on herbal medicine and lactation.

\section{Methods}

Databases such as Pubmed, $C A B$ abstracts, Cochrane clinical trials, HealthStar, CINHAL, and Reprotox were systematically searched for human trials from 1970 till 2010. Reference lists from relevant articles were hand searched.

\section{Results}

Thirty-two studies met the inclusion criteria. Clinical studies were divided into three categories: survey studies $(\mathrm{n}=11)$, safety studies $(\mathrm{n}=8)$, and efficacy studies $(\mathrm{n}=13)$. Six studies were randomized controlled trials. The most common herbs studied were St. John's wort (Hypericum perforatum L.) $(\mathrm{n}=3)$, garlic (Allium sativum L.) extract $(n=2)$, and senna (Cassia senna L.) $(n=2)$. Studies were very heterogeneous with regards to study design, herbal intervention, and outcome measures. Overall, poor methodological quality predominated among the studies.

\section{Conclusion}

Our review concludes that further research is needed to assess the prevalence, efficacy, and safety of herbs during breastfeeding.

\section{Author details \\ ${ }^{1}$ Boston Medical Center, Boston, USA. ${ }^{2}$ Medicinal Plant Program, Dept. of Plant, Soil, and Insect Sciences, Amherst, USA. ${ }^{3}$ Toronto Western Hospital, Toronto, Canada. ${ }^{4}$ Arizona Center for Integrative Medicine, University of Arizona Health, Tucson, USA.}

Boston Medical Center, Boston, USA

Full list of author information is available at the end of the article
Published: 12 June 2012

doi:10.1186/1472-6882-12-S1-P386

Cite this article as: Budzynska et al.: P05.26. Systematic review of breastfeeding and herbs. BMC Complementary and Alternative Medicine 2012 12(Suppl 1):P386.
Submit your next manuscript to BioMed Central and take full advantage of:

- Convenient online submission

- Thorough peer review

- No space constraints or color figure charges

- Immediate publication on acceptance

- Inclusion in PubMed, CAS, Scopus and Google Scholar

- Research which is freely available for redistribution

Submit your manuscript at www.biomedcentral.com/submit
C Biomed Central 